\title{
Third Graders' Perceptions on Moral Behaviour on Bullying If They Had the Infinite Powers of Superhero Defenders
}

\author{
Juha Johansson and Markku S. Hannula \\ Department of Teacher Education, University of Helsinki, P.O. Box 9, 00180 Helsinki, Finland \\ Correspondence should be addressed to Juha Johansson, juha.johansson@edu.hel.fi \\ Received 26 February 2012; Revised 17 May 2012; Accepted 27 May 2012 \\ Academic Editor: Kirsi Tirri
}

Copyright (C) 2012 J. Johansson and M. S. Hannula. This is an open access article distributed under the Creative Commons Attribution License, which permits unrestricted use, distribution, and reproduction in any medium, provided the original work is properly cited.

\begin{abstract}
Bullying is a serious moral concern affecting the victim's welfare and achievement in school. Lately, research on bullying phenomenon has led to successful procedures in which passive bystanders are asked to become defenders of the victims of bullying. This case study explores children's perceptions on moral behaviour on bullying and, moreover, what type of moral voice they would express if they had the infinite powers and means of superhero defenders. Children created masks, posters, and flags for ideal superheroes and described their personalities. In addition, they drew comic strips about the skills they wish to teach new hero students in superhero school. The results indicate that children's moral voices can be divided primarily into justice and care. In addition, some expressed also the dark voice of the vigilante. Findings suggest that superheroes offer one tool for educators and children to ponder about the role of defenders for the victims of bullying. The topic focuses on the core of school life, relationships between pupils, and their moral development. Sixteen third grade children (aged 9-10) from a primary school in Finland took part in the study. The results for two of the children are presented in detail as the basis for discussion.
\end{abstract}

\section{Introduction}

In the classic children's book Alice's Adventures in Wonderland, Alice comes to a crossroads in the forest and asks the Cheshire cat for advice about which way to choose. The cat tells Alice that it depends largely on where she wants to go. Alice says that she does not much care, and the cat replies that in that case it does not matter which path she chooses [1]. Often, choosing a path in life includes making moral decisions and it is not always easy to make the right choice. The awareness of one's destination can assist in making decisions. The conversation between the cat and Alice continues with Alice becoming curious about what type of people live around the different possible paths. The cat tells her that here she is only going to meet mad people. Alice says that she does not want to go among mad people but the cat responds, "Oh, you can't help that. We are all mad here. I'm mad. You're mad." Alice asks the cat how it knows that she is mad too. The cat responds, "You must be or you wouldn't have come here." [1]. Alice experienced nonsense in wonderland where things were opposite to her previous world. Alice has inspired many graphic novelists to write adventures in various wonderlands of nonsense and madness. For example, contemporary superhero cartoonists Morrison and McKean [2] created Arkham Asylum: A Serious House on Serious Earth, which is a fictional story of Batman entering a house for the criminally insane and being bullied by his archenemies. Soon, the book became the best selling original graphic novel in the comics industry. Children face moral dilemmas and crossroads just like Alice did in wonderland. Who could guide them? Pinocchio had to learn to make moral choices before becoming a real boy, and for this purpose Jiminy Cricket was asked to serve as his moral guide and defender on a straight and narrow path [3]. Little Red Riding Hood also met temptations in the forest and was deceived by the wolf. The hunter took the role of defender when he rescued her by shooting the wolf that had eaten her [4].

The roots of this study are in the idea that children can feel in school like Alice, Pinocchio, Batman, and Little Red Riding Hood in their worlds of nonsense and madness. Children need guides and defenders. For first graders on their 
first day, school can be an amazing wonderland. It is like a brand new world with various crossroads, and many new people will enter their lives. First graders may also encounter violence like bullying which makes no sense and is complete madness to them. This study investigates one of the major moral challenges of the core of school life: pupil relationships in terms of bullying. The methodology invites their moral imagination to take the form of a superhero defender to tackle bullying. Often, children feel powerless when faced with serious moral problems. What would happen if they received more powers? This study explores how children see superheroes as defenders in bullying and what type of moral voice they would express if they had infinite powers.

\subsection{Narrative Thinking as Children's Way to Learn Morality.} When children meet virtuous characters in stories, they too want to be good human beings [5]. Stories are a key factor in the moral development of children as they contain morality in action. Stories reach deep into the core of moral life [6]. Stories are a source of information from which children scoop up ideas when they face moral dilemmas in their lives. The purpose of stories is to enrich the readers' moral imagination. From the role models and idols children find in stories, they create prototypes for justice, equality, and love which may not necessarily be found in real life. Thus, children's moral judgments are based on their own knowledge banks which are created from the stories they read [7]. Children's moral responses depend largely on the stories they have read recently [6], and they construct meanings based on their knowledge and previous experiences. However, there is a risk that children may understand the message in very different way to that intended by the author because they are not passive readers, since comprehension of stories depends on the reader's moral development [8].

Both parents tell more stories of caring to girls than to boys, which affects girls' moral orientation [9], while boys are expected to play competitively and aggressively in order to survive in a world of competition [10]. All children have a natural need for stories that contain opposite forces, good and evil [11]. Stories can work as therapy [12].

1.2. Superheroes as Moral Agents. Role models are important when a child forms a moral self and identity [13]. There are various types of role models and heroes in the stories that children read. This study focuses on the superhero genre who are seen mainly as defenders even though they have many roles in saving the world. There is wide agreement about superheroes' role as defenders. Superheroes are defenders of the less fortunate [14], vulnerable [15], innocent [16], powerless [17], weak, and oppressed [18]. They defend fair play [19], truth [20], justice, law, and order [21]. In a nutshell, superheroes are defenders of right against wrong [22]. Their action is based on charity and they see that certain behaviour must be controlled if order is to be maintained. Superheroes have a high social status and moral code [14] and they act in the name of justice as their morality is built on that [23]. Heroes fascinate because of their mythical nature. The comic illustrator David Mazzucchelli [24] points out that orphans like Superman and Moses developed into heroes when they found their hidden specialties. This archetype resonates with a child's early fears and fantasies. Mazzucchelli disagrees with critics who analyze superheroes in terms of an adult sensibility. Superheroes come alive best in a children's world because they were created for them. This is in line with Morrison [23] who protects superheroes from critiques by arguing that children understand that stories have different rules. Adults question how Superman can fly but children know naturally that he is simply not real.

Children admire superheroes as their moral idols. In his empirical study, Martin [25] found a correlation between children's self-rated moral values and morality of their favourite superheroes. However, the correlation was stronger amongst boys. Moreover, Pardales [7] found that children may form their values based on their heroes' values.

Many educators have addressed the violence of superheroes. Violence should not be the determining factor in defining superheroes' moral nature because their violence depends on the social context. They use violence only to prevent villains causing harm to others [25]. Superheroes as defenders exist to solve serious problems and even though this may make violence necessary, they engage in violence without killing [23]. But does every child truly comprehend these facts? There is great danger in young children analysing superhero stories only in terms of images which are often violent. Young children have a tendency to focus their attention on action instead of a character's intentions [26]. Many times superheroes' solution to violence is more violence. Superheroes do not have an official role in their communities as they act more like unofficial security guards of the city. This makes questionable their position as role models and they may even encourage children to take the law into their own hands and thus becoming vigilantes. Superheroes face difficult moral dilemmas. They have a moral responsibility to use their powers and thus cannot remain as silent bystanders. Often there are two forces fighting within them, that is, hero and avenger. Sometimes, the villain makes the superhero choose between two alternatives in deciding whom to save? Another dilemma is that can he jeopardize other people's lives in trying to capture a villain in a dangerous chase.

Besides superheroes there are also everyday heroes without supernatural powers. Everyday heroism is a social concept in which personal virtue, integrity, moral courage, and compassion are turned into meaningful social action when the opportunity arises [27]. Moreover, everyday heroism is about peace, love, generosity of spirit, acts of kindness, and making others feel embraced, understood, and special. Moral courage and a heroic imagination lead to the ability to stand up to injustice and indifference. Becoming an everyday hero is a compassionate calling and answering that call means doing one good deed at a time [28].

1.3. Morality Can Be Analysed in terms of Justice and Care. In order to comprehend the morality of everyday heroes and superheroes, some moral models, which can be related to the 
study of heroism, are introduced. Jean Piaget (1896-1980) studied the cognitive morality of children by observing them playing marble games. He became interested in the "rules of the game" and how children obeyed socially accepted rules and alter them based on their personal morality [29].

Lawrence Kohlberg (1927-1987) continued Piaget's work on cognitive morality by studying the moral reasoning of males when faced with hypothetical moral dilemmas in which they often had to make choices between life and death. Thus, Kohlberg's theory was useful in this study as superheroes face similar types of moral problems in fighting super villains. When Kohlberg applied justice to a hero, he referred to vengeance to hurt or kill ([30], pp. 395397). Kohlberg saw that justice is a principle and a reason for action. There are exceptions to rules, "We know it is sometimes right to kill, because it is sometimes just. The Germans, who tried to kill Hitler were doing right because respect for the equal values of lives demands that we kill someone who is murdering others, in order to save lives." ([30] pp. 39-40.) Kohlberg dominated studies on moral justice for decades and he saw that good behaviour is a developmental process.

There are three levels in the development of children's moral thinking: the preconventional, conventional, and postconventional levels. Next, these levels are described with the emphasis on legal justice because some superheroes act on the borderline between what is legal and what is not. The preconventional level is about obedience to power. A child interprets right and wrong according to punishment and reward or the physical power of the person who enunciates the rules. The punisher is powerful and important [30]. Punishments can be physical with the purpose of hurting the wrongdoer who deserves to be harmed. Children do back to wrongdoers what they did to them [31].

At the conventional level, right behaviour is doing one's duty, and individuals maintain the given social order for its own sake. The punisher is now sympathetic, benevolent, and fair. [30]. Laws are followed strictly except in extreme cases when they conflict with social duties. Thus, circumstances may justify deviant action [31].

At the postconventional, or autonomous, level everyone is equal and principles are abstract like the Golden Rule instead of concrete rules like the Ten Commandments. Individuals define their chosen ethical principles and personal values apart from authority. Individuals do not necessarily identify themselves as part of the "system." The emphasis is still on legality as in the previous level but there is now more willingness to improve laws. The conscience as a directing agent defines what is right. However, right action should be critically agreed upon by the whole of society. The punishment is assessed according to its effects on society as a whole [30]. At this level, individuals consider legal and moral points of views and they recognize that they may conflict. Thus, they feel it challenging to integrate them. Even extreme circumstances do not justify taking the law into one's own hands and a good end does not justify the means, which was typically the case at the previous level ([31], pp. 46, 175.)

Carol Gilligan took a different viewpoint in her study of morality from that of Kohlberg. In her first studies, Gilligan used Kohlberg's method of hypothetical moral dilemmas and she was puzzled because women scored lower compared to men. [32]. In her classical work, Gilligen [33] studied reallife narratives of women and identified in her data moral voices of justice and care. Gilligan concluded that the voice of justice was more typical of men while women expressed more the voice of care. Justice is about rights and rules. Justice arises from duties and a commitment to the obligations of rules and it focuses on equality, reciprocity, and fairness between two people. Care focuses on compassion, empathy, affection, loving, and listening. Care includes the principle of nonviolence, not hurting others, minimizing suffering, the avoidance of pain, and expressing more mercy than justice. Moral development takes place when a person experiences change in the self. Individuals who reach the highest stage of morality do not hurt others or themselves [33]. This study extends these moral voices into the discussion about the superhero genre.

Vollum and Adkinson [14] analysed the morality of justice and they separated this voice into the justice of Batman and Superman who both hold to high moral codes. They both fight for justice, but their methods are different. Superman works only within the bounds of law, trusting rules and regulations, while Batman creates his own law and exalts himself a position where he is a judge. The reason for the difference in their methods arises mainly from the fact that Superman lives in Metropolis, which is the society of consensus while Batman's Gotham City is in a state of conflict and corruption [14]. Superman is merciful knight of daylight and is all about chivalry while Batman is dark knight of grim justice [34] who created his own moral code [35]. Overall, when superheroes fight against evil the term is superjustice [36]. Since superheroes feel responsible for saving society, this study suggests that they can be used to aid children to ponder about one problem in their "daytime" society: school bullying.

1.4. Bullying Damages the Moral Atmosphere of Schools. Bullying is a group phenomenon in which there are altogether six possible participant roles, namely, a bully, the assistant of a bully, a reinforcer of the bully, an outsider, a victim, and a defender of the victim [37]. Bullying is a moral issue because bullies break the moral principles of justice and welfare [38], when they oppress, humiliate [39], and intend to hurt or cause harm to innocent victims [40,41]. Bullies and their assistants construct bullying as unproblematic, justified, and even as a harmless game. Bullies see their victims as odd individuals who deserve such hostile action [42]. Finding a solution to bullying should not be concentrated on curing the bullies' aggressive behaviour alone, as it is difficult to change directly. In addition, it is not fair to expect victims to change because they deserve to be accepted the way they are. Passive bystanders can change the dynamics of a group phenomenon if they step in as defenders to support, help [43], and comfort victims [44]. Bystanders normally a silent majority make meanness acceptable by watching victims being bullied, whereas defenders intervene and save the world by helping one individual at a time. Children are 
more likely to intervene in cases of bullying if others expect them to do so [45].

But, what does it take to defend a victim of bulling? Previous research has identified that those who act as defenders have a strong sense of responsibility [46] and they have a high level of moral sensibility, moral domain [39], top status among peers [47], and social power, that is, perceived popularity, which may be necessary because it protects them against possible revenge from the bully in becoming a future victim [48]. As prosocial individuals they intervene in bullying incidents to help victims [37]. They are talented with sociocognitive skills and have a sophisticated understanding of both the cognitive and emotional states of other persons [39, 49]. Empathy [50], empathic reactivity [49], and affective empathy, that is, feeling another person's feelings is strongly associated with defending behaviour while knowledge of feelings is not necessarily enough and may even be used to cause harm to others [48]. Victims that have been defended by someone else have higher self-esteem and are less depressed [51].

The defenders of victims of bullying seem to have similar qualities to superheroes. This interpretation is not completely new. In fact, Prevent Child Abuse America (PCAA) joined with Marvel Comics in 2003 to fight against bullying by creating special comic book issues in which a superhero prevented bullying. In one story a superhero teaches that those who remain silent bystanders in the face of bullying are not innocent [52]. Marvel Comics President [53] stated at the beginning of the Comics for Compassion campaign that heroes speak on behalf of those who cannot speak for themselves. Possessing great abilities in itself does not make anyone a hero but choosing the right thing to do with these skills does make one a hero.

Another important variable in fighting against bullying is the moral climate of the school. A higher sense of community leads to liking victims more. Children's perceptions about the moral atmosphere in school may affect their behaviour and attitudes towards others [54]. Moreover, stimulating exclusively individuals' moral competency by explicit teaching of moral principles is not enough to change moral behaviour measurably whereas teaching on improving the moral atmosphere of school is more effective [55].

With respect to bullying, Finnish schools are homogenous. Teachers are highly trained and they are legally obliged to tackle bullying [56]. Finnish schools tackle bullying with national antibullying programs. The $\mathrm{KiVa}$ (KiVa is an acronym for Kiusaamista (against bullying) in the Finnish language. Kiva also means nice and friendly) antibullying program was developed in the University of Turku, Finland in 2006. In the experimental stage of the KiVa program, questionnaire studies showed that at different grades $20 \%$ (grades 1-2), 16\% (grades 3-5), and 10\% (grades 7-8) of pupils experienced being bullied several times per month [57]. Since 2009, 75\% of Finnish comprehensive schools have been implementing the program. KiVa has been very successful in reducing bullying and contains concrete and practical tools for teachers to tackle bullying. The KiVa package consists of lessons and themes for pupils, video films, discussions, exercises done in groups, a computer game, an Internet forum, parent's guide, and posters. The actual intervention consists of KiVa teams of teachers who lead discussions with bullies and victims. Furthermore, classroom teachers challenge prosocial classmates to become defenders of victims of bullying [44]. In addition to reducing bullying, KiVa has increased pupils' academic motivation and achievement and overall school well-being. After the intervention, children like school more and perceive the school climate and classroom more positively. KiVa has affected all pupils positively [58]. In addition to KiVa, over 400 Finnish schools also use the VERSO antibullying program which is a student-centered democratic approach in which children mutually solve bullying cases [59].

1.5. Aims of the Study. The aim of the present case study was to explore third graders' perceptions of moral behaviour related to bullying. Often, children feel powerless even though they have a desire to do much more. What would happen if they received few more means or even unlimited powers? The study explores how children see the role of superhero defender and what type of powers received tackle bullying? The precise research question was formulated as follows: what type of moral voice would children express on bullying if they had the infinite powers of superhero defenders? Based on a previous study of moral voices [33], it was expected that the moral voice of children can be separated into care and justice. One new aspect of this study is that every child's narrative was presented in terms of comic strips, masks, posters, flags, and written descriptions of the superhero's character. A narrative which includes different modes of presentation offers third graders various methods to express their moral views, as their writing skills are still developing.

\section{Method}

2.1. Participants. The participants were sixteen (12 girls and 4 boys) third grade children aged 9-10 years who attended a primary school in Finland. The school is located in an urban area. The pupils' home backgrounds in terms of the neighbourhood demographics revealed that the majority came from lower-income families but that there were also a few children from middle-income families. Both the KiVa and VERSO programs are actively used in this school so that KiVa is the "police" in the whole school but VERSO is used in the lower grades (1-3) while KiVa is practised in the upper grades. The participants were chosen by university staff who did not know what this study was about. Investigating children who attend the same classroom ensured that circumstances were similar for each participant. The classroom atmosphere can alter significantly between classrooms. Even the time of day can affect the results.

2.2. Procedure. The project was carried out at the children's own school in April-May 2011. Before collecting the data, the investigator participated in KiVa training at the University of Turku where this program was developed. The time limit for each task was limited to a normal class session, that is, 
45 minutes. At the beginning of each session, the children were given clear instructions orally and they were also written on an interactive whiteboard. The children were free to ask questions. The class teacher made sure everyone understood the instructions. The atmosphere was very concentrated. Actual interviews were not conducted but discussions with each pupil helped to clarify some details. The investigator did not ask specific questions because they can be manipulative in nature. The investigator's goal was to receive explanations that were as spontaneous as possible. The investigator asked mainly, "Would you like to say something about this art work?" Children were free to use either English or Finnish in their art work. In this paper, all the Finnish data is translated into English. All the names appearing in the study are pseudonyms.

2.3. Measures. There are several ways to study how children express their sense of morality. Piaget [29] observed children playing games, Kohlberg [30] created hypothetical moral dilemmas, and Gilligan [33] analysed narratives. This current study supports drawings method as a way to bring forth third graders' moral thinking as their linguistic skills are still developing at this age. Thus, for children who cannot yet express themselves verbally in the way they wish, the artistic method may provide them with ways to express their ideas in a more comfortable and motivating manner. Parsons [60] has studied children's sense of morality in art drawings. He argues that children's art may reveal personal aspects of which even they are unaware. Art is about meanings. When evaluating art drawings, a moral view deals with practical action which affects other individuals. Children's drawings are mostly narrative stories related to their everyday life and problems, which may contain the pondering about good and evil [61]. Children's drawings are one of the ways in which they express what they would like to become $[62,63]$. When children are given a chance to create their own narratives, they can speak out in their own way and have the opportunity to take part in a critical discussion [64]. In this study, the children were given the chance from a superhero perspective to take part in a critical discussion about bullying.

Children's perceptions on the moral behaviour on bullying were measured with five tasks. The children were free to choose a classical superhero or create their own superhero or everyday hero. Children were not given rules concerning what superheroes should look like. The idea for this comes from Morrison's [23] question, namely, what would superheroes look like if they were real? He answered that in making superhero comics there are not any rules.

First, the children made masks for the superheroes which they wished to become. Martin [25] found in his study that when he gave a list of classic superheroes to children to choose from, it favoured boys, who found it easier to identify with superheroes. Therefore, this current study tried to avoid this problem thus giving the children more freedom when identifying themselves with heroes. By not giving the children any list of superheroes from which to choose the children were free to choose either a superhero or an everyday hero. When the masks were ready, a fashion show was conducted, where everyone introduced their masks by making an entry into the classroom as their hero. The show was called "We all wear masks", which is a famous quote by André Berthiaume. The quote is also used in Batman movies and comic books. After the show, the children were asked to wear their masks in the tasks and imagine being that hero. However, they were not forced to do so.

Second, the children wrote about their superheroes' character and how they would interpret the school rules. According to Morrison [23] superheroes' characters have changed over the decades. For example, in the early days it was Batman himself as a person that mattered but these days, when many artists use the same superhero in creating comic stories, it is the combination of creator and the character of the superhero that makes the difference. Therefore, by studying children's versions of the classic superheroes, this study explores some new interpretations of them related to bullying. However, it was expected that some of them might create new heroes and this was regarded as favorable. There were several questions that directed children in describing the personalities of their superheroes and their interpretations of school rules. The following are examples of typical questions. What powers does s/he possess? What does $\mathrm{s} / \mathrm{he}$ defend? What does $s /$ he feel toward others? Interpretations about the importance of school rules were analysed in such a way that they were seen as the laws of their "society."

Third, the children drew posters of their superheroes inviting outsiders to become the hero defenders of the victims of bullying. A poster is one way to campaign for a certain moral cause. Fourth, they drew a flag for their superhero. A flag is also a method to market and boost personal values. Fifth, the children drew comic strips about what skills this superhero could teach future hero defender students in a hero school. The children were asked to divide their paper into four parts and draw one picture in each panel. They were encouraged to write words in the panels.

This report is part of a larger study of bullying. Children also wrote stories about bullying and how the superheroes defend the victims of bullying. In addition, they wrote stories about how these same superheroes handle a situation when they become preys for bullies and victims of bullying. Four narratives were transformed into drama plays in small groups and acted out in front of the classroom. Moreover, they also wrote as superheroes to an imaginary newspaper about how to defend animals against bullying. Furthermore, they wrote stories about their first day in an imaginary school which did not have any rules. Owing to limited space, these assessments are omitted.

2.4. Analysis. The methodology to analyse the comic strips in this study was developed from Rudrum's [65] narrative methodology in which frames represent stages of the events. Moreover, Efland's [61] analysis method, in which children's drawings were mostly narrative stories, was adapted to this study in such a way that the children's artistic moral expression from their art works of comic strips, masks, posters, and flags was evaluated as one long narrative. Their written descriptions of their superhero and the discussions 
between the investigator and each child were considered as supportive material to unite the different parts into one comprehensive narrative. The main point of the analysis was to investigate what moral values children see their superhero using and teaching, care or justice, and how does this relate to the defender's role.

The children were free to create characters for their superheroes and to define their moral codes. Allowing such freedom in assignments yielded different data compared to questionnaire sheets. Skill in combining figures, signs, and words in the panels was considered as an artistic moral expression ability. The moral expression in written descriptions of their superheroes' personalities and discussions were analysed in a similar manner but only in the use of words. To analyse which type of moral voice the superhero expressed in the narrative, the most important criterion was Gilligan's [33] moral voice model which separates morality into the moral voices of justice and care. For this study, an extended model was created based on the theories of Kohlberg [30], Gilligan [33], and Vollum and Adkinson [14]. This model will be introduced with metaphoristic language adapted from Alice's Adventures in Wonderland. First, the children entered the superhero's wonderland by walking the superhero path which provided them with resources to become superheroes. These resources were divided into two categories:

(1) superhero school subjects,

(2) superpower.

Superhero school subjects are skills that aid in the work of superheroes but do not include any mystical or unnatural powers with which to tackle bullying. Instead, superpower provides resources which offer unlimited powers and means. Superpowers are infinite and even mystical in nature. Superpower gives options and choices for the different moral behaviours of care or justice. When the childen received the resources to act as heroes, they faced a crossroads, which either lead to a care or a justice path. Furthermore, the justice path in turn has crossroads of Batman justice and Superman justice. The Superman justice path is a law-abiding commitment to the obligations of rules, that is, a belief that law is functional and honourable. Moreover, this Superman justice includes mercy. The Batman justice path is mainly one that is above the law because the law does not function properly and is corrupted. The justice of Batman is "exitus acta probat" (latin), that is, the end justifies the means. Batman is a merciless outlaw who creates his own moral code and takes the law into his own hands. In this study, walking this path was often required to solve tough moral dilemmas. The care path is all about empathy, love, not hurting others, and abstaining from violence. This care seems to be close to the attributes associated with everyday heroes. If superhero school subjects and superpowers describe the resources and powers that children wish to acquire, then care, Superman justice, and Batman justice are moral behaviours that describe what children would do with those unlimited powers. Thus, children's moral behaviours in tackling bullying were divided into three categories:

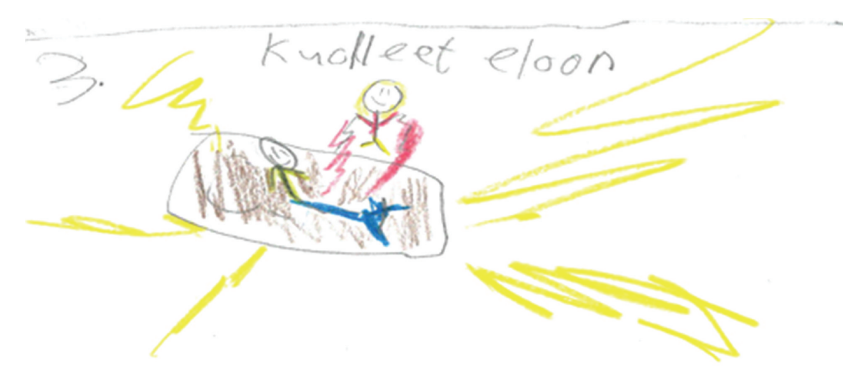

FIgURE 1: This Figure is one panel which includes superpower. Heidi's Dee Dee Girl teaches how to raise the dead. Translation: dead arise.

(1) Superman justice,

(2) Batman justice,

(3) The care of the everyday hero.

Two children were chosen for a detailed and holistic analysis. They were Tomi (boy) and Selina (girl). Focusing only on two children allows more in-depth interpretation of these cases and enables to go beneath the surface. The choice was based on how widely a child walked these different paths and thus expressed variety of moral voices. This is one way to analyze the variety of their moral values and skills. This analysis method offers two trips into these children's personalities and moral worlds.

\section{Results}

3.1. Resource Powers to Tackle Bullying. The following table contains a list of the key resources that were coded and interpreted as expressions of the powers that the children wished to acquire in order to become defenders. Superpowers are unlimited, unnatural, and mystical in nature whereas superhero school subjects do not require unnatural means (Figure 1).

According to Heidi, the superhero is teaching how to raise a dead victim who wants to live. This art work is an example of care toward the victim and it also contains justice because an innocent victim deserves to live. A superpower may combine care and justice. In fact, three girls drew a panel of raising the dead. The drawing by Merja shown in Figure 2 was interpreted as a sign of a superpower because it is unnatural power.

3.2. What Did Children Do with Their Resources? Table 1 includes the key elements that were coded and interpreted as expressions of moral behaviours characterized by care and justice. In many cases, the children were not able to draw clearly especially voices belonging to the moral of care. Therefore, Julia wrote a list of words in one panel. For example, "knowing that you can trust someone" was difficult for her to draw on paper. It should be noted that everyone did not express violent justice as this seemed to be related more to superheroes and not to everyday heroes who seemed 


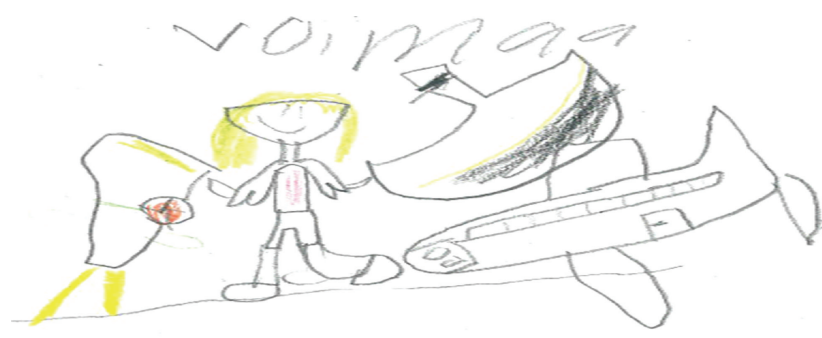

Figure 2: Merja's superhero teaches the power to lift and rescue objects. Translation: power.
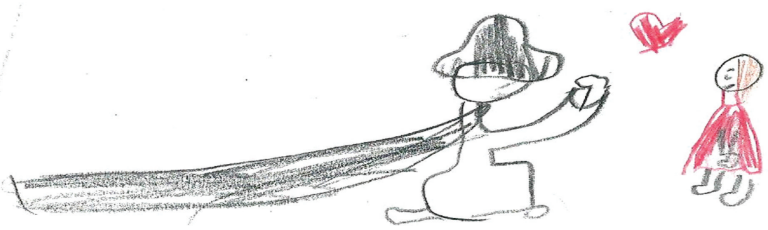

Figure 3: Julia's Zorro has kneeled down and is expressing his feelings towards a weak victim. Zorro is at her service. The heart was interpreted as a strong moral symbol of care. Even though Zorro is drawn totally in black his feelings have been expressed in red.

to be caring heroes. The headings at the top describe the background theories for actual moral categories (Table 2).

3.3. Gilliganian Care Is a Voice of the Everyday Hero. The moral expressions that were close to the Gilliganian type of care, or the care associated with an everyday hero, include codes, signs, symbols, and words like the expression of one's feelings towards others, comforting, affection, tenderness, knowing that you can trust someone, learning not to fight, not being nasty, staying without fear, avoiding fear, having only a small amount of fear inside, maintaining courage, selfcontrol, relaxation, peace, yoga, calming down, not being shy, not being in a hurry, and calling an ambulance. Figures 3 and 4 from the participants' comic strips are typical examples which include the type of care of the everyday hero. It does not include any superpower.

3.4. Kohlbergian Batman Justice. Many moral expressions of children were close to Batman justice. They can be identified at various levels of Kohlberg's legal justice theory. Their expressions included symbols and words like violent killing, attacking in groups, pride, karate, shooting with a gun, violent fights, defending with force, hitting, and fighting with sword. Figures 5 and 6 include the moral voice of Batman justice.

3.5. Kohlbergian Superman Justice. Some moral expressions can be identified as the justice of Superman and they are close to Kohlbergian conventional justice. The expressions include signs, symbols, and words like self-defence, dance assisted defending, using a shooting device and fast action with little

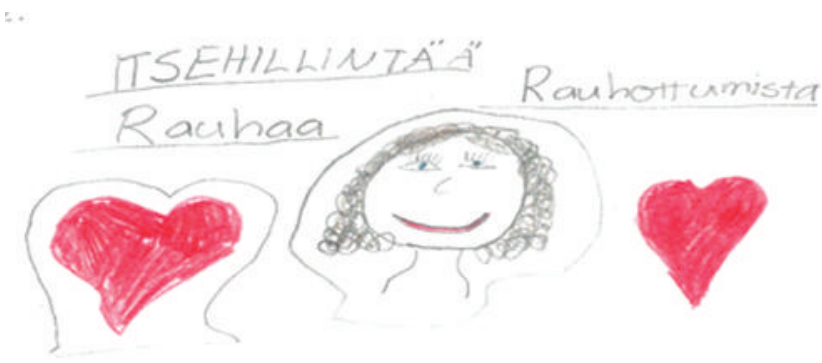

Figure 4: Anne's everyday hero Tiina teaches values related to care. Translation: self-control; peace; calming down.

TABLE 1: Resources to tackle bullying if children had infinite powers.

\begin{tabular}{ll}
\hline Superpower & Superhero school subject \\
\hline Exercising magic & Learning new languages \\
Transforming into an animal & like Russian \\
Flying & Moving silently \\
Walking on hot rocks & Acrobatics \\
Raising the dead & Climbing \\
Spying and moving in the dark & Diving \\
Possessing power over water, fire, & Swimming \\
wind, earth, and sun & Balancing \\
Power to lift an aeroplane & Singing \\
and a ship & Playing instruments \\
Appearing as different people & Learning artistic skills \\
the list also includes symbols & Practising various techniques \\
which combine care and justice &
\end{tabular}
like the Batman logo)

violence. In Figure 6 the punching bag was interpreted as a symbol of Superman justice as it is a legal way to use force. It should be noticed that in Figure 3 Julia's Zorro expressed the clear moral voice of care.

Moreover, this study investigated how superheroes interpret the importance of rules in school. The first key finding was that children who expressed justice and especially Batman justice in their narratives saw that rules were crucial for their safety and well-being. The second finding was that they interpreted the nature of rules to mean that everyone should agree on them.

Tomi (boy) and Selina (girl) managed to take the mantle of superhero as defender expressing different moral voices. Moreover, they saw superhero school subjects to be an important part of a superhero's work. Both superheroes also have dark sides. The investigator did not notice them bullying during this study. The investigator followed up the children by also spending recesses with them outdoors five times with the same results. In general, it can be said that the characters which Tomi and Selina created reflected their personal lives but due to limited space such analysing is kept to a minimum. 
TABLE 2: Children's moral behaviour on bullying if they had infinite powers.

\begin{tabular}{lll}
\hline Gilliganian care & \multicolumn{2}{c}{ Kohlbergian preconventional and conventional justice } \\
Care of everyday hero & Batman justice & Superman justice \\
\hline Feelings towards others & Violent killing & Dance assisted defending \\
Comforting & Attacking in groups & Using a shooting device \\
Affection & Pride & Fast action with little violence \\
Tenderness & Karate & Shooting with a gun \\
Knowing that you can trust someone & Violent fights & Defending with force \\
Learning not to fight & Hitting hard \\
Practising not to be nasty & Fighting with a sword \\
Staying without fear & & \\
Avoiding fear & \\
Having only small amount of fear inside & \\
Maintaining one's courage & \\
Self-control & \\
Relaxation & \\
Peace & \\
Yoga & \\
Calming down & \\
Not being shy & \\
Not being in a hurry & \\
Calling an ambulance & & \\
\hline
\end{tabular}

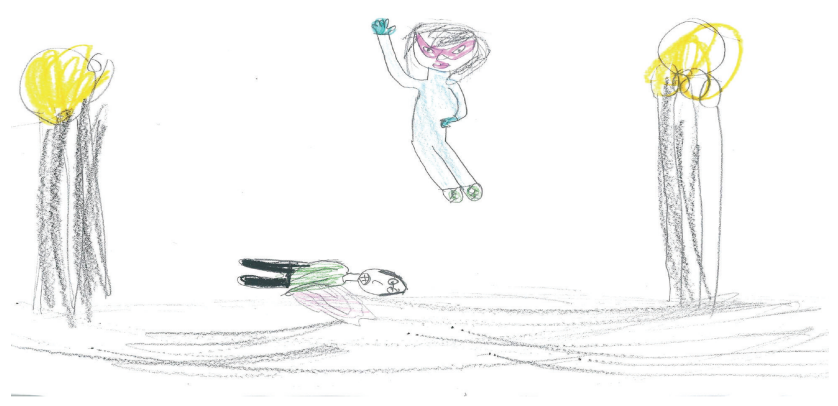

FIGURE 5: Rebekka's World Girl teaches fighting. The victim is dead.

3.5.1. Case 1: Batman Alias Tomi. Batman alias Tomi appeared to be a real Batman fan. In fact, before this study he had written a story about Batman in his notebook when they were given a free choice of topic for a writing assignment. It included exact aspects and details from the world of Batman like Arkham Asylum, and his villain gallery included Joker, Two-Face, Mr. Penquin, Mr. Freeze, Bane, and Riddler, and it all happened in Gotham City. In that story Batman had to make a difficult moral decision and he chose the morally right thing to do. Tomi was excited about this project and he often talked about Batman even in the cafeteria. Tomi said about the original Batman, "Batman is my favourite superhero. He is the best because he helps weaker ones... $\mathrm{He}$ is actually a little bit of an outlaw... Batman is wise. His voice is deep and low while Spiderman's voice is higher." Tomi mentioned that the best Batman movie was Batman Begins [66] but that there are several good ones. Arkham Asylum fascinates Tomi and he understands that it is a mental

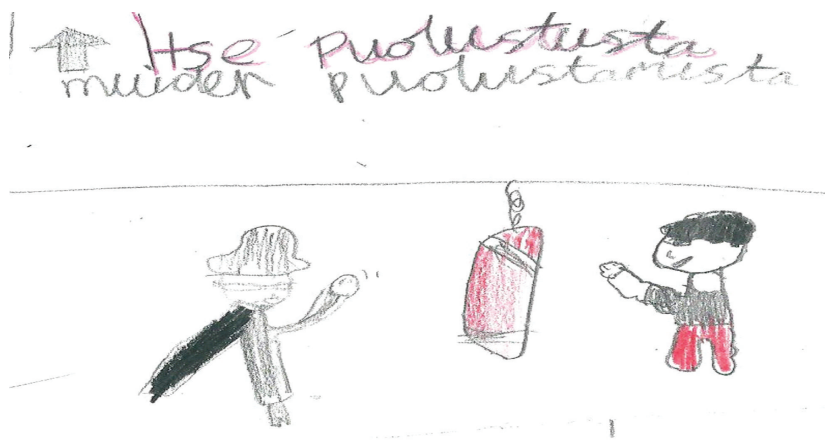

Figure 6: Julia's Zorro teaches self-defence and the defending of others. The figures wear boxing gloves. Translation: self-defence; defending others.

institution for mad villains. He has many Batman comic books at home and he reads them regularly. Tomi also likes to read books about World War II. From this point, the study will refer to Tomi's version of Batman. Batman does not need to use much force to solve bullying cases as bullies are afraid when he appears.

Tomi wrote about Batman's personality and character saying that he has excellent instincts and his hearing is extraordinary. He can fly and he has a lot of assistive devices. He defends justice and good people. He has good feelings towards the citizens. He brings with him a feeling of excitement. He is popular but some people interpret him as evil. Tomi's Batman realizes that without rules in the school there would be no order, instead there would be chaos, and bullying and fighting might occur. Without rules the school 


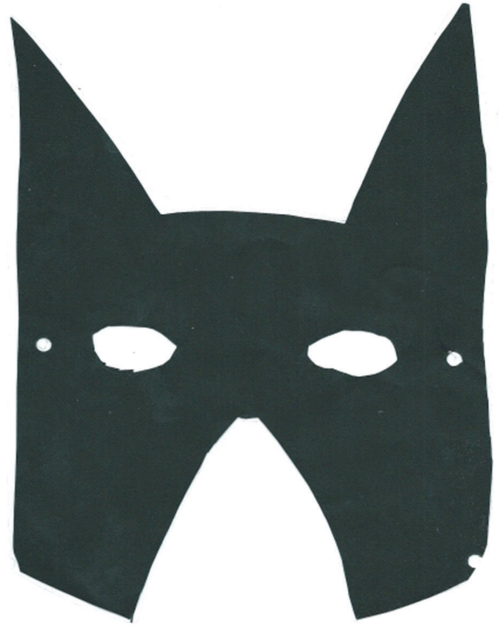

FIGURE 7: Batman mask.

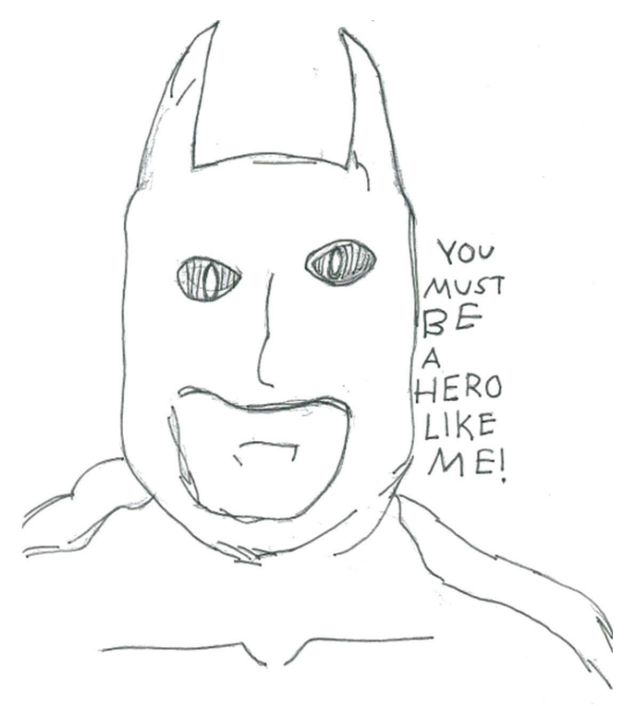

FIgURE 8: Batman poster.

would not be secure. Pupils do not make the rules. Tomi himself seems to be a strict follower of the school rules as he said, "We follow rules which we agree." He sees that it is important that everyone agrees with the rules (Figure 7).

When Tomi introduced his Batman mask his body language expressed confidence and he used a deep and gruff voice which sounded scary. Tomi said that he used black card-board to create the mask in order to cause fear. The mask is also for protection in a fight. Tomi's poster of Batman has both a picture and words. Batman's words "You must be a hero like me" have a commanding sound. It is an invitation to follow his example and become like him. The mouth is wide open (Figure 9).

In the first strip, Batman is showing new heroes how to fight. He does not need guns because he moves fast. Batman is able to fight against many villains at once based on his instincts. This type of cruel fight can be recognized

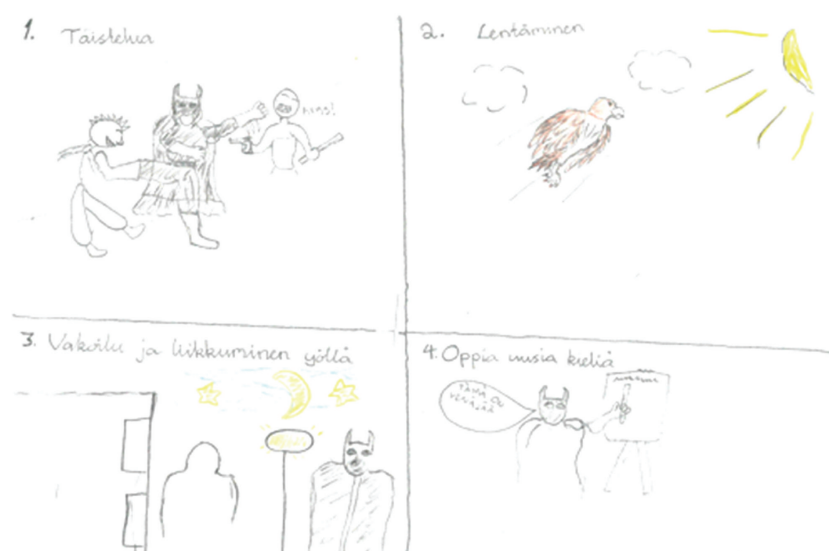

Figure 9: Batman hero school. Translation: panel 1: fighting. 2: flying. 3: spying and moving at night. 4: learning new languages. "This is Russian."

as Batman justice. It should be noticed that this was the first thing that Tomi drew on the paper. In the second strip, hero students practise flying like an eagle which is a superpower. Tomi said that having an ability to fly helps in fights and also helps in rescuing people in trouble. In the third strip, Batman teaches spying and moving at night. Tomi said that Batman spies on villains and also good people in order to protect and help them. This was interpreted as a superpower, although it could also be seen as a superhero school subject. In the fourth strip, Batman is teaching hero students new languages, which they will need to solve crimes. Now he is teaching Russian. This can be referred to as a superhero school subject.

Tomi painted a Batman flag which has a big bat with its wings wide open. It is similar to the Batman logo found in Batman comic books and movies. Tomi said that the flag can be raised up to a flag pool as a sign of his power. The flag is supposed to frighten and offer protection for good people.

Tomi's position among the peer group can be defined as a leader of the other boys. His self-confidence and ability to speak out can be noticed when he gives presentations. Even the teacher recommended that he should be the person who started the presentations in order to show others how to act in front of his peers. Sometimes, he has a hot temper which shows up in sport lessons. He is also the smartest pupil in terms of mathematical skills. The investigator noticed these things (Figure 10).

3.5.2. Case 2: Webwoman Alias Selina. These art works were created by Webwoman alias Selina. Selina created a mask to beautify Webwoman. When Selina introduced her mask she made an impression of a super model. Selina said that the mask has the marks of a spider's web which is a sign of Webwoman. Later, she knitted black webs at home to decorate the eyeholes. She attached them with tape. She used that decorated mask in school even when she was not encouraged to do so. Her poster has both a picture and words. The text says, "I watch you with my eyes at night and day." 


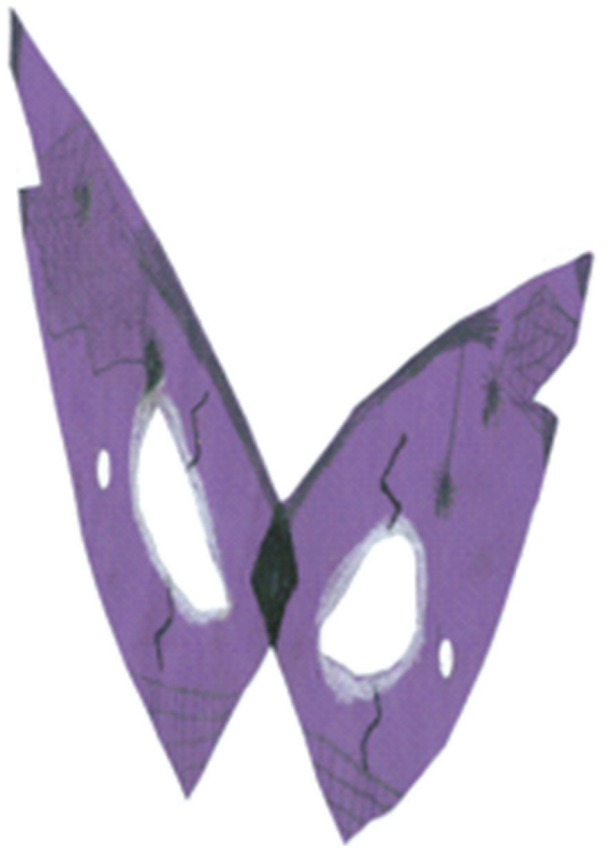

FIgURE 10: Webwoman mask.
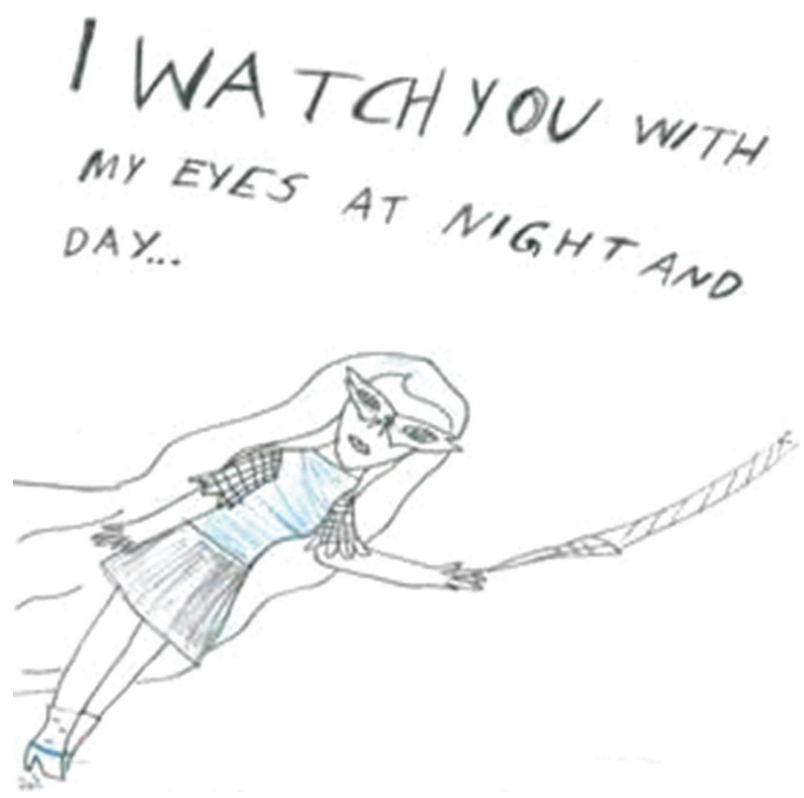

Figure 11: Webwoman poster.

Selina said that she likes Spiderman and she sought inspiration from him in creating her own superhero. According to Selina, first graders are too young for violent defending. For example, sleeping medicine put into candies is a good remedy and makes bullies unconscious. The Webwoman does not kill her enemies as she only makes them lose conscience. She uses a web to transport, for example, bullies home. Selina wrote about Webwoman's personality and character saying that her powers are heatvision, laservision, and intelligence. She shoots a web from her fingers. Webwoman defends

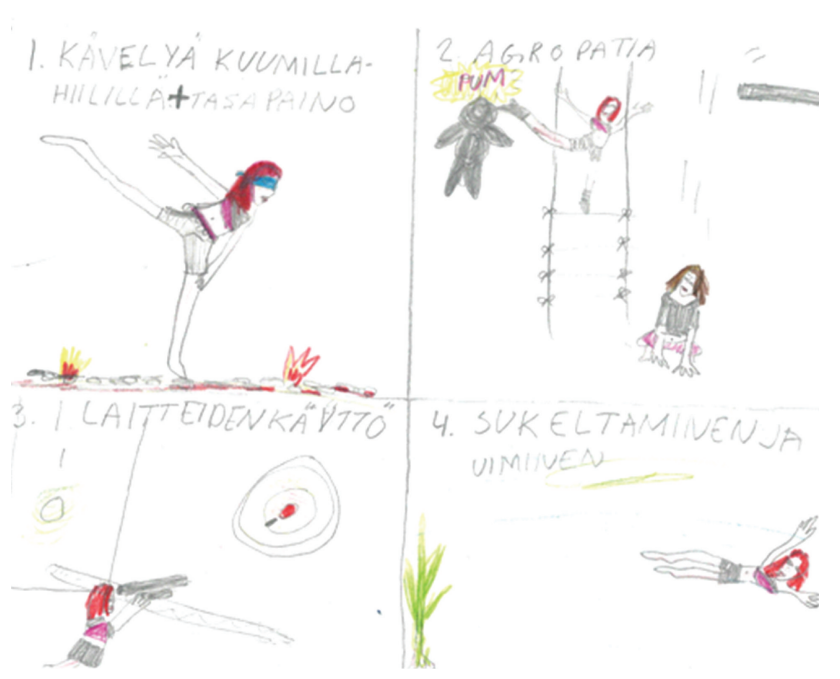

FIGURE 12: Webwoman hero school. Translation: panel 1: walking on hot rocks. 2: acrobatics. 3: using devices. 4: diving and swimming.

justice but she is not entirely a "goodie" in Selina's own words. However, she does not give more details about this. She defends the helpless, the sick, victims of bullying, and discriminated human beings. She brings with her an exciting and beautiful atmosphere. She has contact only with one human being, Loviisa-friend. She is popular only among boys. Selina's Webwoman thinks that rules in school are important so that everyone can feel good in school. School rules are generally agreed upon and they must be suitable for everyone. Without school rules the school would become a mishmash. Selina herself is a follower of the rules but she was once a little rebellious with a teacher giving her a dirty look when she was corrected.

Selina created a flag to symbolize the web making device which Webwoman uses to catch people who are in danger. The web is also used to catch villains. Thus the flag combines the care and Superman justice (Figure 12).

In the first panel, a superhero student is learning to walk on hot rocks whilst keeping her balance. Walking on hot rocks can be considered as a superpower moral because it is an extraordinary skill. The second panel is about acrobatics. A superhero student is learning to kick and thus practising fighting skills in challenging circumstances. This can be categorized as Batman justice because the opponent is hurt. Another student on the right side is learning to fall down, which is a superhero school subject. In the third panel, the student is learning to use devices, which may be Superman justice because it does not necessarily hurt the enemy. The fourth panel is about diving and swimming both of which can be categorized as superhero school subjects.

\section{Discussion}

School is a morally insecure wonderland of nonsense and madness if bullying is not stopped and if it is allowed to destroy the moral climate and student achievement. The 
present case study examined what type of moral voice children would express on bullying if they had the infinite powers of superhero defenders. The key result was that children's moral expressions can be divided mainly into the categories of moral voice of care and justice as Gilligan [33] suggested 30 years ago. In this empirical study two different moral voices of justice were identified and they can be separated into the justice of Batman and Superman as Vollum and Adkinson [14] suggests. In addition, we observed notions of mystical superpowers, which, along with superhero school subjects, were analysed as resources that children wish to acquire in order to tackle bullying. In a way these children were like Alice in Wonderland facing crossroads and they had to choose paths of moral behaviour from various alternatives. The crossroads symbolize the difficult moral choices that children had to make in the wonderland, which had various villages of either chaotic or lawful systems. Entering into the wonderland of superheroes happened when the children put their superhero masks on. First, the children walked the superhero path that provided them with the resources to become superheroes. Superhero school subjects gave them natural skills and superpower provided unlimited powers. Some superpowers were even mystical such as the ability to raise the dead, and these skills can be used for good or evil purposes. Soon, they encountered crossroads which were like temptations concerning how to use those new special resources. They had to make decisions on which way to choose. The first crossroads splits into a care and a justice path. The care path leads to everyday heroism. When children chose to walk the justice path they soon encountered a new crossroads where the road divided into the path of Batman justice and Superman justice. The Batman justice path is filled with darkness and fear. In Batman justice, law had to be broken. If the children keep walking it they are going to find themselves becoming more like Batman. The Superman justice path is bright. Superman lives at the end of that path and he serves as a moral guide and instructor there. Following his example may lead to becoming more like him.

When analysing all 16 narratives, the most chosen moral path was the care path. One reason for the popularity of this path can be found by looking at whom the children directed their moral behaviour. More children were concerned to draw or write about the welfare of the victim, which meant using the care voice more compared to a smaller group of children who were enthusiastic about attacking the bully in the name of justice. Another reason for the popularity of the care path could be that $75 \%$ of children were girls. For example, Selina's Webwoman prefers care when she defends the helpless, the sick, the victims of bullying, and discriminated human beings. In general, the care path seemed to be all about feelings and comforting the victim. This seems to be exactly in line with Gilligan's [33] moral model in which care is nonviolent and it focuses on compassion, empathy, affection, and loving. This is also similar to findings by Gini et al. [39] according to which the defenders of victims of bullying are talented with sociocognitive skills and have a sophisticated understanding of the emotional states of other people. In this current study, walking the care path seemed to mean love, and some girls even drew love signs towards the victim. This is probably what Kärnä et al. [43] meant when they argued that it is not fair to expect victims to change because they deserve to be accepted the way they are. Bystanders should step in as protectors to support and help victims. Similarly, Vollum and Adkinson [14] interprets that a superhero's action is based on charity. The care path and this type of defender's voice seem to fit the qualities of everyday heroes. For instance, Zimbardo [27, 28] sees that everyday heroism is about integrity, compassion, peace, love, generosity of spirit, acts of kindness, and making others feel embraced, understood, and special. Selina's Webwoman walked the care path when she said, "I watch you with my eyes at night and day (Figure 11)." Victims of bullying find peace when they know that superhero is defending them with an all seeing eye 24/7. In fact, the key idea in the KiVa program is that victims should get feeling that everything possible is being done to stop bullying.

The justice path of darkness is guided by Batman. Batman justice can be recognized in Tomi's narrative when Batman taught fighting so that opponents were hurt. When analysing the narratives of the 16 children reported in this paper there were three cases of killing. This contradicts Morrison [23], who states that superheroes as defenders exist to solve problems without killing. This study argues that in the end all that matters is how children see the message that superheroes from media are sending. What about violence without killing? This study has shown that when superheroes are used as a method to study the defender's role, violence seems hard to avoid in the narratives. Most of the children expressed at least some sort of violence and the results indicate that a defender can also be an avenger. This can be analysed as a worrying sign if children see a defender as a vigilante who uses violence even if it is justified in terms of "exitus acta probat". Kohlberg [31] might have analysed this ideology in terms of his conventional moral, as circumstances may justify deviant action. It cannot be a postconventional moral as Kohlberg stated that at that level even extreme circumstances do not justify taking the law into one's own hands as a good end does not justify the means. In this study children who justified violent means by pointing to a right outcome also mentioned defender's qualities that were related to empathy. The schools should have zero tolerance towards any level of violence. Defending with guns and violently hurting someone are methods that lead to dark justice. Punishment seems to be Batman's obsession as an avenger. Tomi's Batman spoke with a deep and scary voice and it had commanding sound, "You must be a hero like me (Figure 8)." It is often neglected in moral voice studies that a moral voice can also be expressed in the sound of the voice. Tomi's Batman is trained to defend justice by fighting harshly and his main weapon against bullies is his ability to cause fear. Because he sometimes breaks the law, some consider him as evil. Kohlberg's [30] preconventional moral is about punishment and obedience to power. Thus, Tomi's Batman also shows signs of a lower level of morality. However, this study does not intend to place children on different moral levels as that type of analysis would require a larger study. However, it seems that Tomi's 
Batman expresses moral voices that indicate a relation with both the preconventional and the conventional levels. In addition, Tomi's Batman's moral expression even has hints of the postconventional level in which individuals consider the legal and moral points of view and recognize that they come into conflict with each other. Thus, it is challenging to integrate them [31].

The second justice path which is bright and guided by Superman seemed to be more popular among girls than boys, who favoured taking steps towards Batman as their idol. Selina's Superman justice can be recognized when she drew a panel in which Webwoman uses a device to shoot target plate. Thus, she is just practising and not actually hurting anyone. Other signs of Superman justice from Selina include the use of a sleeping medicine, rather than killing her enemies, and shooting a web instead of bullets. Kohlberg's [30] conventional level is about fulfilling the expectations of society in following the law. This is more like Superman's method of working as he respects the law of his city. However, Selina also expressed the darker side of justice as being not entirely a "goodie." In order for Batman to work in corrupt Gotham, he must break the law and create his own laws and rules. Superheroes' respect and attitude towards laws are the key aspect when making the difference between the justice of Superman and that of Batman and their different moral paths. Gilligan's [33] justice seems to be closer to Superman as she states that justice arises from a commitment to obey the rules.

Tomi's Batman argues that without order and rules in the school there could be chaos, bullying and fighting. Thus, Tomi's Batman seems to interpret the school system as a kind of Gotham City, which would also be in a state of chaos and constant fighting without Batman ruling over it and keeping strict order. Problems arise if laws are not followed. Batman intervenes if the system does not work. Thus, Batman, who can be above the law, has the keys to the "rules of the game" as Piaget [29] would have put it. Similarly, according to Vollum and Adkinson [14], superheroes see that certain types of behaviour must be controlled if order is to be maintained. In this study, this type of "exitus acta probat" -spirit can lead to another serious form of violence which is madness and nonsense: school shootings. In fact, in one narrative, a child killed a bully with a gun relating the story to school killings and vigilantism.

In previous studies, bullying is correlated to school shootings in a way that most school shooters have experienced a long period of victimization and marginalization by their peers [67]. Children learn at an early stage that schools are unsafe and cruel places where they have to defend themselves in order not to becoming a victim themselves [68]. Students seek guidance at school in constructing their moral identities and when they do not find it they create their own rituals which may take the form of a ceremonial school shooting. Why schools? Children are forced to be in school, so they are ideal places to show off force. Because schools are places to experience humiliation and fear, they are the places chosen to cause humiliation and fear. Schools were violent even before a shot was fired. School shootings as traumatic events cause a community to question its educational systems and values [69]. In the years 2007 and 2008, two dramatic school shootings occurred in Finland, and these tragedies shocked people, because the Nordic welfare society was perceived to be safe [70]. Thus, if the victim of bullying is not protected, he may see school as a corrupt Gothem City and may choose the path of an avenging Batman. To become a superhero, one needs superpowers, and school shooters by having guns obtain great powers. It may also be that an extreme and twisted worshipping of superhero vigilantes, who take the law into their own hands, leads to school shootings. Pardales [7] found that children may form their values based on their heroes. At least, this current study has shown that imagining powers of a superhero gives some warning signs as some children's narratives included violent killing, which they saw as an acceptable way to handle bullying. Lately, the media has discussed the case of the Norwegian Anders Breivik who killed 69 people on the camp on the island of Utøya. When children enter the superhero wonderland they face supervillains similar to Breivik. Another real life "super villain" Osama bin Laden was killed in a US assault, providing an example of Batman justice in the real world. This study tried to find out how children see morality in relation to bullying. The logic of caring which is often emphasized in school lessons does not necessarily cure cases such as Breivik and Osama bin Laden. Kohlberg himself wrote that it is sometimes justified to kill in order to save lives [30]. However, he did not mention that it is necessarily the highest level of morality.

The superpower path which includes gaining the resources to behave as a hero led to a crossroads at which the road splits into a care and a justice path. Selina's Webwoman's superpower is a web which is a soft saving device for rescuing the innocent and a hard device for capturing villains and bullies. Webwoman thinks that rules in school are important and that everyone should feel good in school. Moreover, she feels that school rules are generally agreed upon and that they must be suitable for everyone. In these sentences it is easy to identify both the paths of care and justice. Feeling good in school is close to what Gilligan [33] means by caring. Generally agreed school rules which are suitable for everyone are exactly how Gilligan [33] interprets justice as it focuses on equality, reciprocity, and fairness between people. The superpower path leads to a crossroads where children feel challenged to integrate moral points of view and rules which may conflict with each other. These children did not always stay within the boundaries of a "goodie" citizen as they got lost in a cold and dreary wonderland and even became "a little bit of an outlaw" in finding the correct path. Thus, they also expressed the dark side of their specialities. Possessing great powers led in some cases to violent behaviour. Great powers offer the chance of losing oneself to evil or the possibility of becoming a legend or a saint. Tomi and Selena did not just choose one path but walked many paths. It seems to be that superheroes face tough moral dilemmas in deciding what to do with their superpowers, which leads to them using both moral voices. When children imagine gaining great powers, they encounter similar moral dilemmas as superheroes in the media. In school shootings guns symbolise great powers. 
Some superhero school subjects raise questions like why are these skills taught to hero students? Tomi's Batman sees it important to teach Russian which will help in work. It should be noticed that Finland has been at war with Russia many times, which has caused a fear of Russia. Does Tomi see a possible threat? He is aware of wars, as he mentioned reading books about World War II.

Besides superheroes' roles as defenders, this study also investigated their role in creating the general school atmosphere. Selina's Webwoman brings with her an exciting and beautiful atmosphere. Like Webwoman, Tomi's Batman also brings with him a feeling of excitement. These types of school atmospheres could help in tackling bullying. Batman is popular but Webwoman is popular only among boys. This can be interpreted as meaning that superheroes are a more boys' thing. In fact, some girls favored creating everyday heroes as all four boys were "obsessed" with superhero idolism. In general, children interpreted their hero as popular, and in this respect superheroes seem to fit the role of defender of victims of bullying. Caravita et al. [47] found that defenders have a top status among their peers, and Pöyhönen et al. [48] concluded that they also have social power, that is, perceived popularity.

Can the influence of the KiVa program be recognized in these children's narratives? SM Girl alias Sanni mentioned in her narrative that her leader had asked SM Girl to defend a girl who had been bullied. This seems to reflect the KiVa program as it is at the core of the program that a classroom teacher should challenge prosocial classmates to become defenders of victims of bullying [44].

Would there be a preference for one superhero moral over another, is Superman's justice superior to Batman's? Superman sends criminals to prison but is that going to change them. In some cases, prisoners only become worse in prison. Superman seems to be for the "status quo", keeping things the way they are without changes in the long run. In Dark Knight [71] Joker says to Batman, "You've changed things, forever." If children's experiences make them believe that the system is not able to protect them from bullying, they may begin to consider taking the law into their own hands. When assigned as a defender, a child may have similar feelings. Their morality may become what Kohlberg [31] would call postconventional as individuals consider legal and moral points of views and recognize that they may conflict. Thus, they feel it challenging to integrate them. In this study children's superheroes' moral choices between two justice paths often depended on how satisfied they felt about the system of school rules. Those who chose the socalled Batman path expressed more forcefully the view that without rules school would be chaotic and that these rules should be agreed upon by everyone. Moreover, it can be concluded that in law-abiding cases the school rules were seen to be functional and this led to children choosing the Superman justice path. When school rules do not work perfectly they see that they are "corrupt" and they may feel that they have the right to put themselves above the law. When the law is "corrupt," tackling bullying requires tough moral decisions. Batman's justice as punishing moral seems to be before the law and order level (preconventional) in
Kohlberg's [31] terms or then after corruption if analysed by Vollum and Adkinson [14]. In other words the Batman justice is the morality of precivilization or postcorruption. Fear rules at the preconventional level. On a law-abiding level everything is black and white, but at the next level children have to make difficult choices which bring forth challenges. In school children are taught ideal morals like the Golden Rule which refers to moral of care. Children admire teachers who are fair and just towards all pupils. Often the reality is far from such ideals and children get disappointed when confronted with the fact that the system simply does not work.

When Alice entered the wonderland she did not want to go among mad people. Similarly, children do not always have a choice; they cannot choose their school, classmates, and teacher. Thus, they may experience adventures in bullying wonderland and some of them will get lost. Some are lucky when they get a defender like Selina's Webwoman who comforts them, saying, "I watch you with my eyes at night and day" (Figure 11). These words can also be directed to a bully. In a nutshell, the moral voice of care seems to be enough for everyday heroes to act as defenders while superheroes need superpowers to fulfil their duties in bringing justice to the bully.

\section{Conclusion}

Although this is a case study and the data was collected from only 16 children and only four of them were boys, it appears that children's art works can be used as a narrative method that offers children a clear way to express a variety of moral voices related to bullying. What are the benefits of these findings for the field of moral education and research on bullying? Besides violent nature, superhero imagination may provide new material for discussing bullying as some children have grown up in world of superheroes. Superheroes can boost children's imagination to explore new ways of producing material about how they would solve bullying if they had more powers. Normally, small children feel powerless. But what would they do if they received unlimited powers one day? Even if superheroes have their dark side, they still offer one tool to stimulate discussion and ponder about bullying and the role of defenders. At least, through this study it is possible to interpret children's inner desires, values, and moral voices.

Superheroes are the unofficial security guards of their territories, who supervise that the rules are followed. This fact may attract, especially, boys' attention to do something about safety in schools. Schools should be safe institutions where children should not feel threatened as they have the right to feel safe and protected. The question is do children see the school system as Gotham City or Metropolis? Children's writings about school rules refer more to Metropolis. The teacher's role as a moral educator to secure protection and bullying-free atmosphere becomes an important issue in school pedagogy which should ensure student wellbeing and achievement. Without rules, schools may become wonderlands of chaos and madness. Problems like bullying 
can arise when students break the rules. Schools should have strong moral protectors and defenders. If current moral education emphasizes the teachings related to care, does it develop boys' morality in an idealistic way?

The narratives included many smart details and clues for further studies. For example, Webwoman could be a defender of victims of bullying in the World Wide Web, where bullying madness and nonsense is spreading. What would children with unlimited powers do about bullying in the internet? Currently, there are not enough fairy tales about how to behave in the internet.

Why is this study important for educators? It discusses the general state of the current school system and its failure to defend the victims of bullying. Thus, superheroes were invited to supervise the school. The study could be improved by taking one more dimension into consideration; what about a world where nobody monitors children? What are their power and position in the world outside school?

\section{References}

[1] L. Carroll, Alice's Adventures in Wonderland, Penquin Books, London, UK, 1865/1994.

[2] G. Morrison and D. McKean, Arkham Asylum. A Serious House on Serious Earth, Detective Comics, New York, NY, USA, 1989.

[3] W. Disney, Pinocchio. Walt Disney classics. Buena Vista Home Video, Beaumont House, London, UK, 1941.

[4] J. W. Grimm, Kinder und Hausmärchen, Eugen Diederichs, Köln, Germany, 1962.

[5] M. B. Tappan, "Moral education in the zone of proximal development," Journal of Moral Education, vol. 27, no. 2, pp. 141-161, 1998.

[6] P. C. Vitz, "The use of stories in moral development: new psychological reasons for an old education method," American Psychologist, vol. 45, no. 6, pp. 709-720, 1990.

[7] M. J. Pardales, "So, how did you arrive at that decision? Connecting moral imagination and moral judgement," Journal of Moral Education, vol. 31, no. 4, pp. 423-437, 2002.

[8] D. Narvaez, "Moral text comprehension: implications for education and research," Journal of Moral Education, vol. 30, no. 1, pp. 42-54, 2001.

[9] M. Pratt, M. Arnold, and S. Hilberg, "A narrative approach to the study of moral orientation in the family: tales of kindness and care," in Personality Development in Adolescence: a CrossNational and Lifespan Perspective, E. Skoe and A. Von Der Lippe, Eds., pp. 61-79, Routledge, London, UK, 1998.

[10] E. E. A. Skoe, A. Cumberland, N. Eisenberg, K. Hansen, and J. Perry, "The influences of sex and gender-role identity on moral cognition and prosocial personality traits," Sex Roles, vol. 46, no. 9-10, pp. 295-309, 2002.

[11] K. Egan, Educational Development, Oxford University Press, New York, NY, USA, 1979.

[12] K. Kidd, "'A' is for Auschwitz: Psychoanalysis, trauma theory, and the 'children's literature of atrocity", Children's Literature, vol. 35, pp. 120-149, 2005.

[13] A. A. Bucher, "The influence of models in forming moral identity," International Journal of Educational Research, vol. 27, no. 7, pp. 619-627, 1998.

[14] S. Vollum and C. D. Adkinson, "The portrayal of crime and justice in the comic book superhero mythos," Journal of
Criminal Justice and Popular Culture, vol. 10, no. 2, pp. 96108, 2003.

[15] P. Paik, From Utopia to Apocalypse: Science Fiction and the Politics of Catastrophe, University of Minnesota Press, Minneapolis, Minn, USA, 2010.

[16] D. Okum, Superhero Madness, F \& W Publications, Cincinnati, Ohio, USA, 2004.

[17] G. McKay and S. Maybell, Calming the Family Storm: Anger Management for Moms, Dads, and All Other Kids, Impact, Atascadero, Calif, USA, 2004.

[18] M. Harney, "Mythogenesis of the modern super hero," in Modern Myths, D. Bevan, Ed., pp. 189-210, Rodopi B.V., Amsterdam, The Netherlands, 1993.

[19] W. Schoell, Comic Book Heroes of the Screen, Citadel Press, New York, NY, USA, 1991.

[20] J. Musler, Unleashing the Superheroes in Us All, Lulu Enterprises, North Carolina, NC, USA, 2006.

[21] D. Migliore, The Power of God and the Gods of Power, Westminster John Knox Press, Louisville, Ky, USA, 2008.

[22] L. Jacobson, Raising Children: Children and the American Mass Market in the Early Twentieth Century, Princeton University Press, Oxford, UK, 2004.

[23] G. Morrison, Supergods: Our World in the Age of the Superhero, Randon House, London, UK, 2011.

[24] D. Mazzucchelli, “The caped crusader," in Batman: Year One, D. Didio, Ed., pp. 100-103, DC Comics, New York, NY, USA, 2005.

[25] J. F. Martin, “Children's attitudes toward superheroes as a potential indicator of their moral understanding," Journal of Moral Education, vol. 36, no. 2, pp. 239-250, 2007.

[26] P. Kendeou, J. Lynch, P. van den Broek, C. Espin, M. White, and K. Kremer, "Developing successful readers: building early comprehension skills through television viewing and listening," Early Childhood Education Journal, vol. 33, no. 2, pp. 91-98, 2005.

[27] P. Zimbardo, "We need a hero," Futurist, vol. 44, no. 6, pp. 2526, 2010.

[28] P. Zimbardo, "Why the world needs heroes?" Europe's Journal of Psychology, vol. 7, pp. 402-407, 2011.

[29] J. Piaget, The Moral Judgment of the Child, The Free Press, New York, NY, USA, 1932.

[30] L. Kohlberg, The Philosophy of Moral Development. Moral Stages and the Idea of Justice, Harper \& Row, San Francisco, Calif, USA, 1981.

[31] L. Kohlberg, The Psychology of Moral Development, Harper \& Row, San Francisco, Calif, USA, 1984.

[32] G. Jorgensen, "Kohlberg and Gilligan: duet or duel?" Journal of Moral Education, vol. 35, no. 2, pp. 179-196, 2006.

[33] C. Gilligan, In a Different Voice. Psychological Theory and Women's Development, Harward University Press, Cambridge, Mass, USA, 1982.

[34] J. Wright, "Heroes of darkness and light," in Batman Unauthorized: Vigilantes, Jokers, and Heroes in Gotham City, A. Porter, Ed., pp. 181-196, BenBella Books, Dallas, Tex, USA, 2008.

[35] D. Fingeroth, Superman on the Couch: What Superheroes Really Tell Us about Ourselves and Our Society, Continuum, New York, NY, USA, 2004.

[36] J. Gabilliet, "1994 Cultural and mythical aspects of a superhero: the silver surfer 1968-1970," The Journal of Popular Culture, vol. 28, pp. 203-213, 1994.

[37] C. Salmivalli, K. Lagerspetz, K. Björkqvist, K. Österman, and A. Kaukiainen, "Bullying as a group process: participant roles and their relations to social status within the group," Aggressive Behavior, vol. 22, pp. 1-15, 1996. 
[38] W. F. Arsenio and E. A. Lemerise, "Aggression and moral development: integrating social information processing and moral domain models," Child Development, vol. 75, no. 4, pp. 987-1002, 2004.

[39] G. Gini, T. Pozzoli, and M. Hauser, "Bullies have enhanced moral competence to judge relative to victims, but lack moral compassion," Personality and Individual Differences, vol. 50, no. 5, pp. 603-608, 2011.

[40] S. L. Bosacki, Z. A. Marini, and A. V. Dane, "Voices from the classroom: pictorial and narrative representations of children's bullying experiences," Journal of Moral Education, vol. 35, no. 2, pp. 231-245, 2006.

[41] L. Nucci, "Finding commonalities: social information processing and domain theory in the study of aggression," Child Development, vol. 75, no. 4, pp. 1009-1012, 2004.

[42] T. Teräsahjo and C. Salmivalli, "'she is not actually bullied.' the discourse of harassment in student groups," Aggressive Behavior, vol. 29, no. 2, pp. 134-154, 2003.

[43] A. Kärnä, M. Voeten, E. Poskiparta, and C. Salmivalli, "Vulnerable children in varying classroom contexts bystanders' behaviors moderate the effects of risk factors on victimization," Merrill-Palmer Quarterly, vol. 56, no. 3, pp. 261-282, 2010.

[44] C. Salmivalli, A. Kärnä, and E. Poskiparta, "Counteracting bullying in Finland: the KiVa program and its effects on different forms of being bullied," International Journal of Behavioral Development, vol. 35, pp. 405-411, 2011.

[45] C. Carter, "Raising happiness: how to raise a hero ," Psychology Today. In press.

[46] T. Pozzoli and G. Gini, "Active defending and passive bystanding behavior in bullying: the role of personal characteristics and perceived peer pressure," Journal of Abnormal Child Psychology, vol. 38, no. 6, pp. 815-827, 2010.

[47] S. C. S. Caravita, P. Di Blasio, and C. Salmivalli, "Unique and interactive effects of empathy and social status on involvement in bullying," Social Development, vol. 18, no. 1, pp. 140-163, 2009.

[48] V. Pöyhönen, J. Juvonen, and C. Salmivalli, "What does it take to stand up for the victim of bullying? The interplay between personal and social factors," Merrill-Palmer Quarterly, vol. 56, no. 2, pp. 143-163, 2010.

[49] G. Gini, "Social cognition and moral cognition in bullying: what's wrong?" Aggressive Behavior, vol. 32, no. 6, pp. 528-539, 2006.

[50] G. Gini, P. Albiero, B. Benelli, and G. Altoè, "Does empathy predict adolescents' bullying and defending behavior?" Aggressive Behavior, vol. 33, no. 5, pp. 467-476, 2007.

[51] M. Sainio, R. Veenstra, G. Huitsing, and C. Salmivalli, "Victims and their defenders: a dyadic approach," International Journal of Behavioral Development, vol. 35, no. 2, pp. 144-151, 2011.

[52] R. De Angelis, Standing Up for the Underdog: Teaching Bullies a Lesson in Comparison, Animal Quardian, 2003.

[53] B. Jemas, "A message from the president of Marvel Comics," X-Men Unlimited, 44, 2, 2003.

[54] G. Gini, "Italian elementary and middle school students' blaming the victim of bullying and perception of school moral atmosphere," Elementary School Journal, vol. 108, no. 4, pp. 335-354, 2008.

[55] D. Brugman, P. G. Heymans, J. Boom, A. I. Podolskij, O. Karabanova, and O. Idobaeva, "Perception of moral atmosphere in school and norm transgressive behaviour in adolescents: an intervention study," International Journal of Behavioral Development, vol. 27, no. 4, pp. 289-300, 2003.
[56] A. Kärnä, M. Voeten, T. D. Little, E. Poskiparta, A. Kaljonen, and C. Salmivalli, "A large-scale evaluation of the KiVa antibullying program: grades 4-6," Child Development, vol. 82, no. 1, pp. 311-330, 2011.

[57] M. Sainio, A. Kaukiainen, U. Willför-Nyman, T. Annevirta, V. Pöyhönen, and T. Salmivalli, KiVa koulu: opettajan opas yläkoululle. Turun yliopiston psykologian laitoksen tutkimuksesta käytäntöön -julkaisusarja, 2009.

[58] C. Salmivalli, C. Garandeau, and R. Veenstra, "KiVa antibullying program: implications for school adjustment," in Peer Relationships and Adjustment at School, G. Ladd and A. Ryan, Eds., 2012.

[59] M. Gellin, Lapsikin osaa sovitella. Minkälaista oppimista restoratiivinen toiminta tuottaa? http://www.avi.fi/fi/virastot/ itasuomenavi/Ajankohtaista/tapahtumat/Koulutusmateriaalit /Documents/SOVITTELU\%20KOULUSSA\%20-\%20Tukea \%20ja\%20tietoa\%20kouluty\%C3\%B6h\%C3\%B6n\% 2011.4.2012,\%20Joensuu/Gellin_Artikkeli.pdf, 2011.

[60] M. Parsons, How We Understand Art: A Cognitive Developmental Account of Aesthetic Experience, Cambridge University Press, New York, NY, USA, 1987.

[61] A. Efland, Art and Cognition: Integrating The Visual Arts in The Curriculum, Reston, New York, NY, USA, 2002.

[62] A. Nicolopoulou, "Worldmaking and identity formation in children's narrative play-acting," in Children's Development within Social Context, L. T. Winegar and J. Valsiner, Eds., pp. 157-185, Lawrence Erlbaum, Hillsdale, NJ, USA, 1992.

[63] A. Nicolopoulou, B. Scales, and J. Weintraub, "Gender differences and symbolic imagination in the stories of four-yearolds," in The Need for Story: Cultural Diversity in Classroom and Community, A. H. Dyson and C. Genishi, Eds., pp. 102123, National Council of Teachers of English, Urbana, Ill, USA, 1994.

[64] R. T. Bourke, "First graders and fairy tales: one teacher's action research of critical literacy," Reading Teacher, vol. 62, no. 4, pp. 304-312, 2008.

[65] D. Rudrum, "From narrative representation to narrative use: towards the limits of definition," Narrative, vol. 13, no. 2, pp. 195-204, 2005.

[66] C. Nolan, Batman Begins [Motion Picture], Warner Brothers, Burbank, Calif, USA, 2005.

[67] M. R. Leary, R. M. Kowalski, L. Smith, and S. Phillips, "Teasing, rejection and violence: case studies of the school shootings," Aggressive Behavior, vol. 29, no. 3, pp. 202-214, 2003.

[68] M. Lebrun, Books, Blackboards, and Bullets: School Shootings and Violence in America, R \& L Education, Lanham, Md, USA, 2009.

[69] B. R. Warnick, B. A. Johnson, and S. Rocha, "Tragedy and the meaning of school shootings," Educational Theory, vol. 60, no. 3, pp. 371-390, 2010.

[70] A. Oksanen, P. Räsänen, J. Nurmi, and K. Lindström, “This can't happen here!," Community Reactions to School Shootings in Finland, vol. 3, pp. 19-27, 2010.

[71] C. Nolan, The Dark Knight [Motion Picture], Warner Brothers, Burbank, Calif, USA, 2008. 


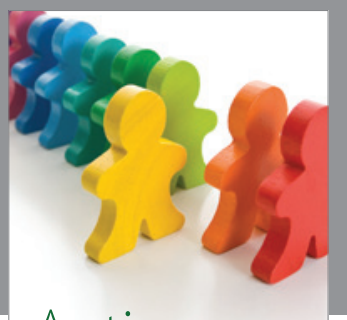

Autism

Research and Treatment
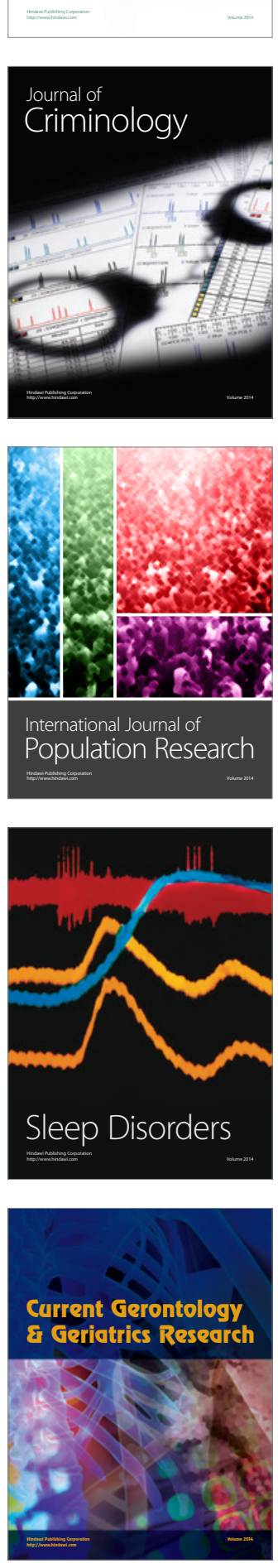
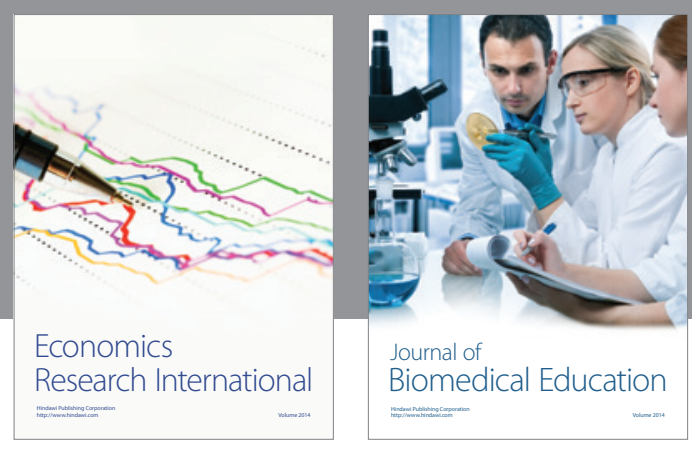

Journal of

Biomedical Education

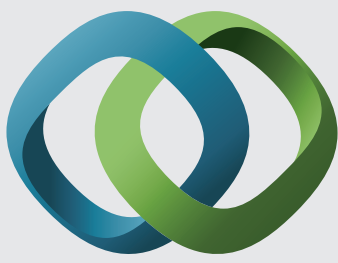

\section{Hindawi}

Submit your manuscripts at

http://www.hindawi.com
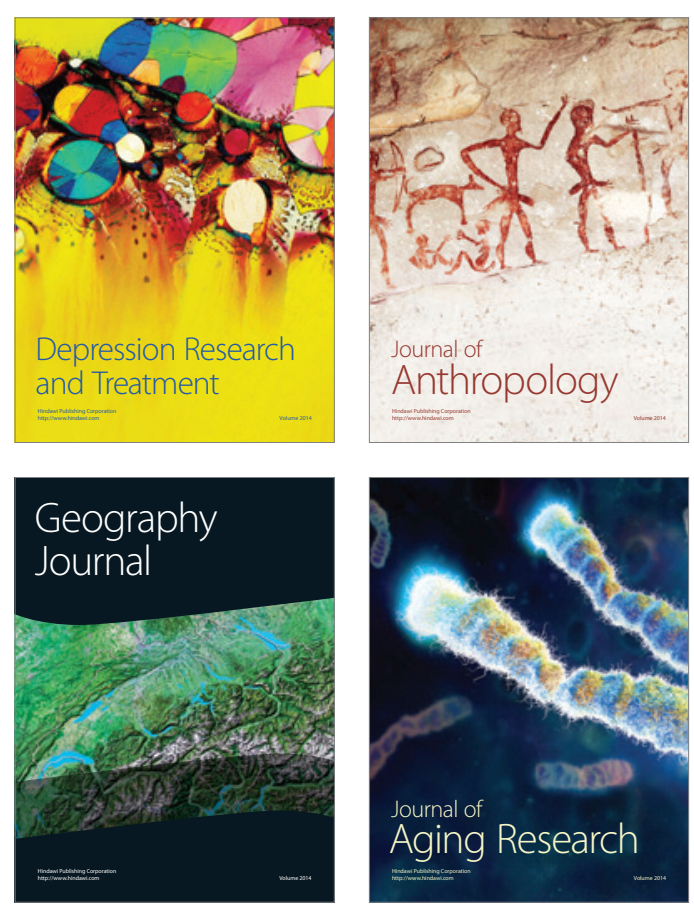

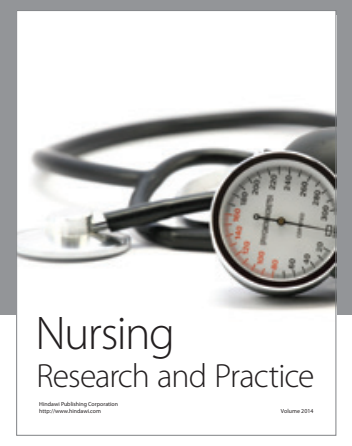

Nursing

Research and Practice

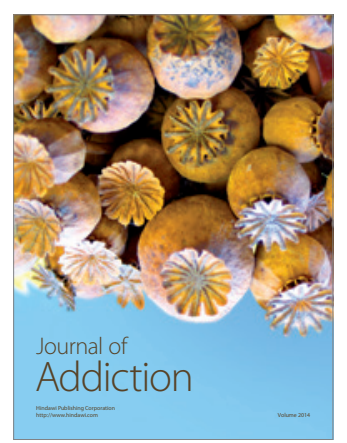

Child Development

Research

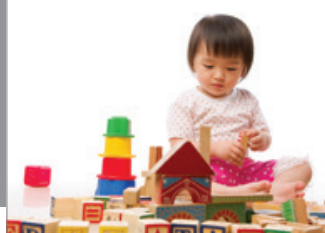

迥
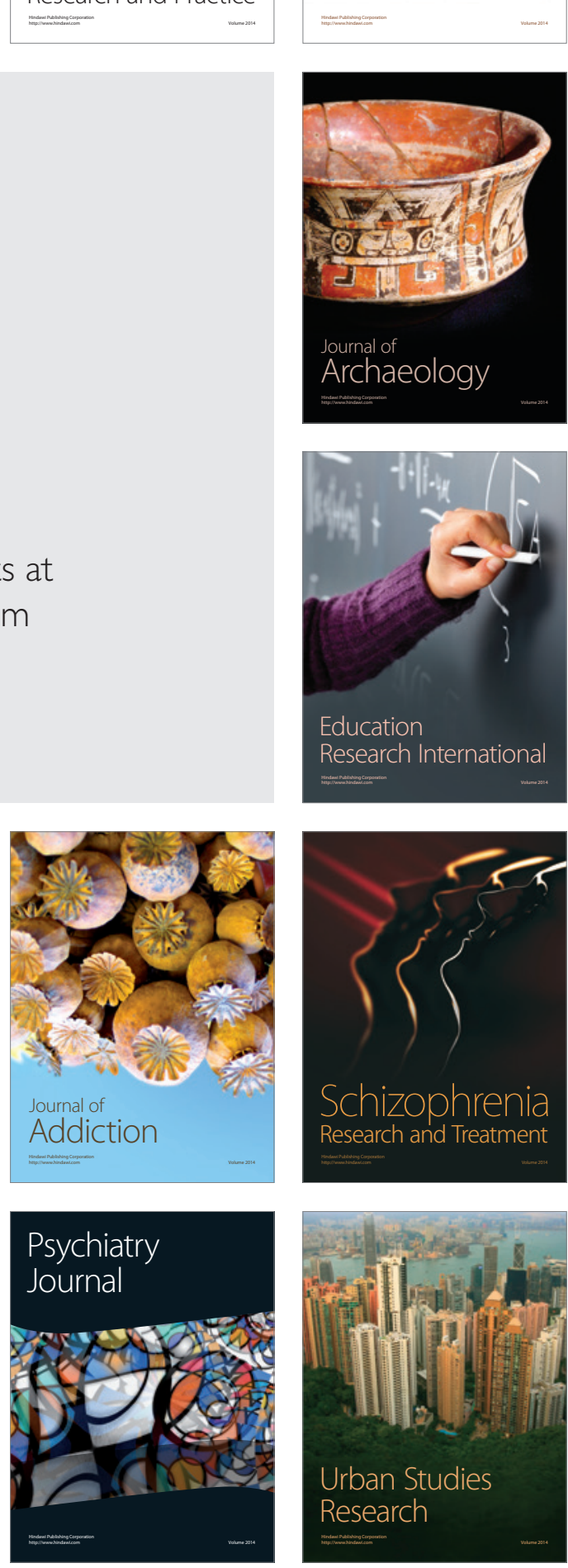